\title{
PUBLIC INFORMATION AND COMMUNICATION SPACE IN UKRAINE: current state, problems and tasks
}

Key words: public administration, information policy, information and communication technologies, legislation, e-governance.

\begin{abstract}
The article conducts a comprehensive study of public information and communication space in Ukraine, analyzes its current state considering regulatory and organizational features, identifies key challenges for quality development and modernization of the industry, and identifies key dysfunctional problems that prevent high performance in domestic development of information and communication technologies. It is argued that an important role in the constructive formation of the public information and communication sector is played by the state information policy, which should be based on such principles as openness, system, equality of interests, priority of domestic producers, social orientation. It turns out that the formation of a quality public information space contributes to the development of civil society, information society and information democracy. Comprehensive digitalization of public communication will promote openness, transparency and accessibility of public information, the formation of partnerships between the public, business, and civil sectors. Three basic stages of formation of information and communication space have been identified: strategic, organizational and control ones.
\end{abstract}

It is revealed that today in Ukraine there is a satisfactory regulatory framework that regulates the public information and communication space: the Law of Ukraine "On Printed Mass Media (Press) in Ukraine", the Law of Ukraine "On Television and Radio Broadcasting", the Law of Ukraine "On Electronic Communications", the Law of Ukraine "On Publishing", the Law of Ukraine "On Information", Law of Ukraine "On Ensuring the Functioning of the Ukrainian

1 PhD student at the Public Administration Department, Educational and Scientific Institute of Public Administration and Civil Service of the Taras Shevchenko National University of Kyiv, vedmid_p@ukr.net. ORCID: 0000-0002-2586-680X. 
Language as the State Language", the Law of Ukraine "On the Procedure for Coverage of Public Authorities and Local Self-Government Bodies in Ukraine by Mass Media", the Law Of Ukraine "On state support of mass media and social protection of journalists", the Law of Ukraine "On news agencies", etc.

It is concluded that solving key problems (imperfection of the system of professional training in the field of ICT, features of development of the domestic IT industry, uneven distribution of information and communication technologies in the regions of Ukraine) in the domestic ICT sector will accelerate Ukraine's approach to the results of advanced countries.

\section{INTRODUCTION}

The rapid development of information and communication technologies has led to significant changes in the organization, coordination and functioning of public space. Dissemination of information and communication within the public sector has acquired new features, channels, and tools. As a result, information and communication exchange has accelerated, become more open and accessible. First of all, radical changes took place with the introduction of e-government, the transition to a service model. The public, private and civil sectors have switched to a partnership format, which contributes to the further improvement of the public information and communication space.

Modern scientific research on a given topic differs in terms of issues. Today in the research literature we could find many studies devoted to the theoretical justification of information and communication space in the public dimension, analysis of internal and external communication technologies, digitization of public services. However, the relevant theoretical developments mostly summarize the best world experience, and less detail the situation in Ukraine. That is why the purpose of the article is to find out the current state, problems and tasks of the public information and communication space in Ukraine. During work such scientific methods as system, structural-functional, analytical ones were used, which allowed to carry out a comprehensive study of the selected problem. 


\section{SIGNIFICANCE OF STATE INFORMATION POLICY}

The information policy of the state plays an important role in the development and planning of the information and communication space. State information policy is an effective tool for the functioning of the information society and foresees the involvement in political life of various social groups, free access to power and priority areas of domestic and foreign policy. The democratization of the state is also due to the state information policy, which in turn contributes to the strengthening of civil society, the interests of its subjects and the protection of their rights and freedoms.

The normative and legal documents regulating the functioning of the public information and communication space in Ukraine include: the Law of Ukraine "On Printed Mass Media (Press) in Ukraine", the Law of Ukraine "On Television and Radio Broadcasting", the Law of Ukraine "On Electronic Communications", the Law of Ukraine "On Publishing”, the Law of Ukraine "On Information", Law of Ukraine "On Ensuring the Functioning of the Ukrainian Language as the State Language", the Law of Ukraine "On the Procedure for Coverage of Public Authorities and Local SelfGovernment Bodies in Ukraine by Mass Media", the Law Of Ukraine "On state support of mass media and social protection of journalists", the Law of Ukraine "On news agencies", the Law of Ukraine "On state support of book publishing in Ukraine", the Law of Ukraine "On reforming state and municipal print media", the Law of Ukraine "On the obligatory copy of documents", the Decree of the President of Ukraine "On some issues of state support of book publishing", the Decree of the President of Ukraine "On some measures for the development of book publishing in Ukraine", the Decree of the President of Ukraine "On some measures for state support of book publishing and popularization of reading in Ukraine", the Resolution of the Cabinet of Ministers of Ukraine "On the Procedure for Delivering Mandatory Copies of Documents", the Resolution of the Cabinet of Ministers of Ukraine "On Supporting Creative Unions and Publishing", the Resolution of the Cabinet of Ministers of Ukraine "On Approval of the State Register of Publishers, Manufacturers and Distributors", the Resolution of the Cabinet of Ministers of Ukraine "On measures to perpetuate the memory of defenders of Ukraine until 2025", the Order 
of the Cabinet of Ministers of Ukraine "On approval of a plan of measures to strengthen national unity, consolidate Ukrainian society and support public initiatives in this area", etc.

Article two of the Law of Ukraine "On Information" defines the basic principles of information relations:

- guaranteed right to information;

- openness, availability of information, freedom of information exchange;

- reliability and completeness of information;

- freedom of expression of views and beliefs;

- legality of receiving, using, disseminating, storing and protecting information;

- protection of a person from interference in his/her personal and family life.

The third article states that the main directions of the state information policy are:

- ensuring everyone's access to information;

- ensuring equal opportunities for the creation, collection, receipt, storage, use, dissemination, protection, protection of information;

- creating conditions for the formation of the information society in Ukraine;

- ensuring openness and transparency of the subjects of power;

- creation of information systems and information networks, development of e-government;

- constant updating, enrichment and storage of national information resources;

- ensuring information security of Ukraine;

- promotion of international cooperation in the field of information and Ukraine's entry into the world information space (Law of Ukraine On Information, 2020).

The implementation of a purposeful state information policy contributes to the construction of an information society, which is considered by civilized states as the basis for further economic, political and socio-cultural development. Ukraine's state information policy has a strategic goal, which is to build a democratic information society and the country's entry 
into the global information community. In turn, the main objectives of the state information policy can be identified from the strategic goal, such as: improvement of information and telecommunication infrastructure; formation and use of the national information resource and ensuring wide access to it; development of information and telecommunication technologies; providing citizens with socially significant information and development of independent mass media; creation and constant improvement of the regulatory framework for building an information society; human preparation for the conditions of the information society.

In the conditions of formation of civil society in Ukraine, the state information policy should be based on the following basic principles: the principle of policy openness, which is manifested in the fact that information policy measures are discussed openly by society and the state takes into account public opinion; the principle of systematization, which stipulates that in the process of implementing the decisions taken when changing the state of one of the objects of regulation must take into account the consequences of this for the state of other objects and all together; the principle of equality of interests, which stipulates that the policy equally takes into account the interests of all participants in information activities, regardless of their position in society and the form of ownership of the information resource; the principle of priority of the domestic producer - under equal conditions the priority is given to the competitive domestic producer of information and communication means; the principle of social orientation, which stipulates that the main measures of state information policy should be aimed at ensuring the social interests of the citizens of Ukraine, etc.

Analyzing the state information policy, it can be concluded that it should be aimed at solving national tasks, such as: the formation of the information space of Ukraine and its entry into the world information space; development of information services; expanding the legal framework governing public relations, including those related to the receipt, dissemination and use of information; increasing political stability in the country; ensuring information security of society and the state. To solve these problems requires effective management of all types of information resources, elements of information and telecommunications infrastruc- 
ture, state support of the domestic market of information technologies, tools, products and services and regulation of state electronic and print media.

The Ukrainian scientist $\mathrm{H}$. Nesvit notes the growing influence of the media on politics and argues that the state information policy is associated with the understanding that building an information society in Ukraine is the main condition for its socio-economic and political development, the formation of a democratic mass consciousness, expanding legal fields of regulation of relations in society (Nesvit, 2001, p. 265).

The functioning of institutions of society and the state significantly depends on how widely modern information technologies are used in all spheres of public life, and the effective operation of information and telecommunication systems, preservation of information resources, in turn, is an important component of national information infrastructure.

It is also necessary to find out the essential characteristics of the information policy of Ukraine in the conditions of modern state formation. The development of the information sphere is of special importance for the formation of a new form of political culture and information democracy in Ukraine. Information democracy, in turn, would ensure information development based on the national idea through a balance between the right to freedom of speech, the free expression of one's views and beliefs, the free circulation of information and the need to ensure national security. Domestic political scientist M. Rozumnyi believes that such a balance will protect the interests of the state, maintain morality and spirituality in society, promote the realization of information rights of citizens (Rozumnyi, 2006, p. 397).

\section{MAIN STAGES OF INFORMATION AND COMMUNICATION SPACE FORMATION}

In my opinion, it is worth distinguishing several stages of the strategy of forming a public information and communication space. The first stage is strategic. It relates to the formation of normative-legal and legislative support of the state policy on the use and management of the national infor- 
mation resources of Ukraine. At the strategic stage, national interests and priorities in the information sphere are determined. Legal bases for further development of the system of national information resources and its management are also formed; the functions and their distribution between the organizational structures which are created for achievement of the strategic purposes are defined; the legal and organizational principles of financial, personnel, logistical, informational, and other types of strategic support of the management system of national information resources are laid down.

At the second stage, organizational and normative-methodical, it is necessary to ensure the implementation of normative-legal and legislative acts, control over the formation, protection, and dissemination of information resources. Also, at the second stage, the central executive bodies provide regulatory and methodological, organizational support for the implementation of legislation, political and legal decisions of the President of Ukraine, the Verkhovna Rada of Ukraine, the Cabinet of Ministers of Ukraine, control over the use, formation, and protection of information resources.

The third stage is control. At this stage, the implementation of regulations and legislation is ensured, as well as control over the established procedure and rules for the formation, dissemination and use of information resources.

Unfortunately, today in Ukraine there is no single strategy for the formation and development of the information society, which would determine the goals, objectives and tools for the formation and improvement of the domestic information and communication space in the public sphere. At the beginning of 2007, the Law of Ukraine "On the Basic Principles of Development of the Information Society of Ukraine for 2007-2015" was adopted. In August 2007, the Action Plan for the implementation of the tasks of this law was adopted (the Order of the Cabinet of Ministers of 15.08.2007 № 653-r). According to this plan, only in 2012 the National System of Indicators for the Development of the "Information Society" in Ukraine was adopted (the Resolution of the Cabinet of Ministers № 1134), and in 2013 - the Strategy for the Development of the "Information Society" (the CMU Decision № 386-r). 
The practice of implementing political decisions to build an "information society" and informatize Ukraine is contradictory and situational. A significant list of measures of the planned programs and plans has been implemented, but they remain fragmentary, and the current regulatory framework of the information and communication sphere of Ukraine remains incomplete, inefficient and contradictory. To improve the situation, it is necessary to develop and implement three system documents: "Information Code of Ukraine", "Information Society Development Strategy" and "National System of Information Society Development Indicators". These documents could help to eliminate the factual discrepancy between the meaning of the term "information society" and practical matters, which are more aimed at solving technological rather than social issues.

In general, the country is rapidly forming a massive Internet audience and a specific network socio-cultural environment, which in its parameters will be like those in developed countries. Audience diversification continues, new models of information consumption, social and political activity, etc. are being formed. At the same time, there is a number of negative phenomena and processes that inhibit the development of the "information society" in Ukraine, such as: low rates of development (lower than the world average) and, accordingly, low ratings of Ukraine in international comparisons; lack of systemic, multilevel, normatively supported, based on a certain ideology and strategy of state policy in the field of information and communication; significant imbalance of the Internet audience by regional, age and property characteristics; low development of high-speed Internet access networks; shortage of qualified personnel due to the outflow of talented young people in commercial structures and in the shadow, export-oriented business of software development.

\section{KEY PROBLEMS OF ICT IN UKRAINE}

In the field of information and communication technologies of Ukraine there are the following problems. Imperfection of the system of professional training in the field of ICT. In recent years, Ukraine has seen a significant 
attention of the economically active population to this area, there are many options for employment in foreign IT companies with decent wages, career growth, good conditions, and opportunities to work even remotely, but there is a lack of highly qualified professionals in the labor market of Ukraine that could work on the domestic platform. This is supported by the outflow of IT brains abroad and the focus of employees only on employment in foreign companies, resulting in the process of exporting financial capital to other countries. Therefore, it is very important to create a proper educational basis for training and development of ICT industry of professionals in Ukraine.

The market of IT technologies in Ukraine is developing rapidly because our country is rich in talented professionals who want to develop in the IT field. However, the country exports most of the services and products of the industry abroad, because in our country it is not always profitable to sell developments of young IT companies and startups.

Features of development of the domestic IT industry. In recent years, there has been a significant demand in the world for types of outsourcing services - personnel, accounting, and IT outsourcing, where the latter has the largest scale of use. The IT outsourcing service allows you to transfer part of the work of a company to organizations specializing in IT. This form of economic cooperation allows you to reduce the company's costs and get a quality end product. The trend of using information technology outsourcing in the business processes of the world has not escaped our country, where there are all the conditions for the development of outsourcing activities. The formation of such a situation is influenced by the fact that specialists from Eastern Europe have a high level of training in this field and agree to pay, which is quite low by European standards.

Uneven distribution of information and communication technologies in the regions of Ukraine. One of the main reasons for Ukraine's low places in the Rating of Information and Communication Technologies Development is the insufficient development of information and technology infrastructure. According to this indicator, Ukraine lags far behind other countries, as the lack of uniform distribution of the Internet, and consequently the insufficient use of modern communication technologies by the population, slows down the process of "digitalization" of the state. 
Rural residents are not always able to connect to the Internet, and those who have managed to do so often deal with technical problems. In fact, in today's world this is a significant problem, as the unavailability of digital technologies for the educational process in villages and small towns contributes to the continued use of outdated teaching methods, which worsens the preparation of students for future higher education. This also applies to the creation of jobs for rural residents, who also do not always keep pace with digital progress due to limited access to the network or even simply lack of awareness of the latest technologies used not only around the world but also by the majority of Ukraine.

Info-communication infrastructure is an important factor in the development of high-tech industries in Ukraine. Transformations in this direction will be able to raise the IT industry of our country to a new, modern stage of development.

\section{CONCLUSIONS}

The study allows us to talk about the dynamic, but sometimes unsystematic development of public information and communication space, which can be partly explained by the lack of a unified strategy and the prevalence of more pressing socio-political challenges. At the same time, it is possible to state the positive dynamics of the formation of the regulatory framework for the organization of public information and communication space in Ukraine, a clear understanding of the leading tasks in the industry. Solving key problems in the domestic ICT sector will accelerate Ukraine's approach to the results of advanced countries.

\section{BIBLIOGRAPHY:}

Law of Ukraine On Information. Electronic resources. Downloaded from: https://zakon. rada.gov.ua/laws/show/2657-12?lang=en\#Text.

Marszałek-Kawa, J., Plecka, D. (ed.). (2019). J. Marszałek-Kawa, D. Plecka (eds.). Dictionary of Political Knowledge. Toruń: Wydawnictwo Adam Marszałek. 
Nesvit, H. (2001). Informatsiina polityka yak faktor transformatsii suspilstva [Information policy as a factor of society transformation]. Kyiv: Instytut politychnykh i etnonatsionalnykh doslidzhen NAN Ukrainy.

Rozumnyi, M. (2006). Natsionalna ideia : vidkrytist novomu i svitu yak intehratsiinyi oriientyr ukrainskoho suspilstva [National idea: openness to the new and the world as integration landmark of the Ukrainian society]. Kyiv: Etnos. 